Original Research Paper

\title{
Interaction between Universities and Businesses in the Youth Labor Market in Russia
}

\author{
${ }^{1}$ Yury Vladimirovich Mishalchenko, ${ }^{2}$ Elena Eugenievna Tarando, \\ ${ }^{2}$ Alexander Fedoseevich Borisov, ${ }^{2}$ Nikolay Alexandrovich Pruel and ${ }^{2}$ Tatiana Borisovna Malinina \\ ${ }^{I}$ Department of International Relations, Saint-Petersburg State University, Saint-Petersburg, Russia \\ ${ }^{2}$ Department of Sociology, Saint-Petersburg State University, Saint-Petersburg, Russia
}

\author{
Article history \\ Received: 06-12-2015 \\ Revised: 28-03-2016 \\ Accepted: 29-03-2016 \\ Corresponding Author: \\ Elena E. Tarando \\ Department of Sociology, \\ Saint-Petersburg State \\ University, Saint-Petersburg, \\ Russia \\ Email: elena.tarando@mail.ru
}

\begin{abstract}
The article analyzes the specific aspects of interaction between government, businesses and higher education in the Russian youth labor market. The carried out analysis of documents regulating the youth employment enabled us to identify the basic aspects of state regulation in this sphere that can facilitate the cooperation between businesses and universities. The authors conducted a survey among the competent representatives of higher education and business to investigate how these parties interact when solving the problems of youth employment. The research identifies the main forms of the interaction between business and universities in Russia. The authors concluded that there is a current trend of strengthening interaction between universities and businesses regarding the employment of university graduates, although the state still plays a significant role in regulating their employment.
\end{abstract}

Keywords: Youth Labor Market, University Graduate Employment, State Youth Employment Policy, Graduate Employment by Businesses, Career Guidance

\section{Introduction}

The effectiveness of any economy is to a large extent determined by how it uses its human resources; the latter can be classified into a number of different groups according to various criteria. Age is one of the most important criteria and in this sense, different age groups in the labor market have different conditions for fulfilling their working potential. Youth is an important part of the labor force: Its effective employment determines not only the present state of a country's economy, but its future in general.

In Russia, the youth labor market faces many problems impeding its successful functioning, varying from the difficulties of young people choosing their future profession to the problems of job search and adaptation in the workplace. The following article explores the principles, methods and technologies of interaction between higher education and business, whose purpose is optimization of the university graduates' employment in modern Russia. This issue is especially relevant since the Soviet system of training and use of human resources has been almost completely destroyed, while a new system, adapted to a market economy, is still evolving.

\section{Literature Review}

The issues of the youth labor market have been investigated quite well by researchers. One of the most studied aspects here is the analysis of how macroeconomic processes influence the functioning of the youth labor market (Signorelli and Cloudhry, 2015; Junakar, 2015; Voronov et al., 2014). In this regard, the following sociological research papers appear to be highly relevant: The analysis of the gender differences impact on the youth employment (Hardi, 2015; Lalthapersad-Pillay, 2014; Kapustkina, 2008), the study of the influence family and parenthood have on the behavior of young people in the labor market (Bezrukova, 2014; 2013), the analysis of sociological approaches to the study of the youth labor market (Ivanov, 2013; 2012; Dudina, 2015; 2013), the role of trust in social interactions in the youth labor market (Kapustkina et al., 2008; Rubtcova et al., 2015c; Sasaky et al., 2013; Hardgrove et al., 2015; Fong and Tsutsui, 2015; Aceleanu et al., 2015; Grigoryeva, 2015), the study of social practices of young professionals recruitment (Rubtsova et al., 2015; Vasilieva et al., 2015; Rasskazov et al., 2016). There are also unconventional research papers analyzing the relationship between the 
youth employment and everyday eating practices formed by transnational corporations (Veselov, 2015). Functioning of the youth labor market has also become the object of management sociology, which analyzes the issues of regulation on this market (Rubtsova, 2011; 2007), as well as various types of young people's behavior concerning their employment (Rubtcova et al., 2015a).

There are quite many studies investigating the regional characteristics of the youth labor market (Adamoniene and Astromskienne, 2013; Alegre et al., 2015; Alzua et al., 2015; Kamimura and Soma, 2013), including those related to Russia (Rubtcova et al., 2015b; Demidova et al., 2015).

Issues of the interaction between the subjects of the youth labor market have also been examined by researchers. Here, the most thoroughly studied are the issues of the relationship of education (including higher school) and youth employment (Premand et al., 2016; Alegre et al., 2015; Herault and Zakirova, 2015). Researchers also analyze the issues of the state policy on the youth employment and how it influences the functioning of the youth labor market (Alegre et al., 2015; Crepon et al., 2013).

It is emphasized in the scientific literature that the youth labor market in Russia is specific, it is characterized by special contradictions, such as the contradiction between the modern professions and outdated educational standards, the contradiction between the rapid workforce aging and the lack of effective mechanisms for its renewal, as well as the absence or lack of effectiveness of the social mobility means, which hinders the progress of youth in the chosen field (Lopatkin, 2015). These contradictions are implemented through a number of problems, namely hidden unemployment, informal registration of labor relations between the employee and the employer, the differences between the labor expectations of the students and the actual employer offers, employment of students at work not related to their specialty (Potravnaya, 2015). It is noted that a significant proportion of graduates who had found job, do not work in the specialty (Borisova and Timofeeva, 2014). To solve these problems, a number of recommendations are offered, including the need to build a network of contacts of universities with large enterprises medium-sized businesses (Chekanova, 2015; Vasiliev, 2014; Matrosova and Gukasova, 2014). At the same time, the issues of organization and content of such contacts in the economic space of Russia are insufficiently analyzed in the scientific literature.

\section{Methodology}

The political-cultural approach in the economic sociology became a methodological basis of the study. Under this approach, the main purpose of market actors is to establish stable conditions for the companies' successful activity in the markets where these companies operate. To this end, a company builds various social relations with their partners (suppliers and customers) and competitors, which allows stabilizing markets of resources and finished products for this particular company. Informational content of these social relations is made by all sorts of social strategies enabling to build relationships with partners and competitors so that the company would take a worthy stable place in the system of this particular market. Successful strategies quickly are institutionalized and copied by other market actors, though for each particular actor its each individual strategy has a certain share of uniqueness (Fligstein, 2001).

As applied to our research, this approach assumes that the surveyed companies seek to secure a stable position in the labor market as a market of one of the resources. To this end, they build strategies for cooperation with universities as suppliers of promising labor. These strategies have a different substantive content, depending on the economic, historical and social conditions in which this particular strategy can be copied by other market actors, which results in the need to identify the advantages and disadvantages of this particular strategy.

As for universities, they tend to occupy a weighty position in the educational market, where employability of their graduates becomes one of the conditions to achieve success. Therefore, universities are also interested in cooperation with employers, resulting in the creation and institutionalization of the appropriate social strategies, implemented through their interaction with the business structures.

The purpose of the research is to identify the peculiarities of interaction between business structures and higher educational institutions in the youth labor market in modern Russia. Instrumentalization of the purpose led to the selection of a number of tasks. The main of these problems include:

- Description of the general economic characteristics of young people as a form of the workforce

- Characteristics of the main social practices of interaction between business and higher education in the plane of addressing youth employment issues

Two mainly used groups of methods contributed to the solution of these tasks. The first group consisted of the methods for qualitative analysis of valid statistical information that characterizes the various parameters of the youth labor market in Russia. This group of methods is aimed at the analysis of the general economic characteristics of young people as a form of workforce. Statistical information was taken from official sources, 
posted on the website of the Federal Service of State Statistics of the RF and the Official site of administration of St. Petersburg. The most recent data published in the specified official sources refer to 2015. In addition, the official statistical publication 'Youth in Russia' was used, which published the statistics on youth. It should be noted that this edition comes out every five years. The latest edition was published in the late 2010-early 2011, so the most recent data on youth relate to 2010 .

The second group of methods was used to characterize the social practices of interaction between business and higher education. Semi-structured expert interviews formed its basis.

Three groups of experts has been allocated, including, first of all, the representatives of the state bodies responsible for the development and implementation of the state youth policy and in particular in relation to the government regulation of the youth labor market (Rosmolodezh)-2 interviews; secondly, the representatives of the higher education, responsible for communication with potential employers (representatives of various universities)-5 interviews; third, the representatives of businesses that have successfully cooperated with universities in terms of the graduates' employability (6 interviews). A list of questions containing from 9 to 13 items was developed for each group of experts. The study by this group of methods was carried out in April-May 2015.

Thus, a mixed strategy was applied in the course of the research, combining the principles, methods for empirical data compilation and analysis of quantitative (in this case-a descriptive one) and qualitative strategies in order to obtain more justified and reliable results.

\section{General Characteristics of the Youth Labor Market in Russia}

A characteristic feature of the youth labor market in the 1990-2000s was that employers demanded a university degree from a candidate for the vacant position. As a reaction to this requirement, there was a dramatic increase in the number of higher educational institutions, primarily commercial, over that period. Thus, the number of graduates from these institutions also increased, which is proven by the statistics (Table 1).

These figures show how much (almost 40 times) the number of graduates of non-state universities increased during the reform period. Since that time a person of any age has been able to enroll at a Russian university, while the age requirement for higher education that existed in Soviet times and did not allow persons over 36 to enter the university has been canceled. However, it is more difficult for older people to obtain higher education due to social, economic, demographic and psychological reasons. Therefore, the bulk of the graduates are young people of appropriate age.
The number of university graduates increased due to the demographic potential inherent from Soviet times, especially before perestroika, when the birth rate was quite high. However, this high birth rate was followed by a "demographic pit" of the 90 s post-reform years. In the late 2000s many universities, both state and private ones, fell into this pit. For example, if in 2002 the group aged 15-19 (the age range, when most people enter university) amounted to 12,801 thousand people, in 2014 this figure was almost half the number-only 6956 thousand people (Federal State Statistics Service of the Russian Federation). Here it should be noted that Russian students, according to sociological studies, do not come from all social groups: Their social origin is rather narrow.

At the same time higher professional education varies in the level of qualifications obtained, as demonstrated by the following figures.

As can be seen from the data, for the period from 1995 to 2010 there was an almost threefold increase in the number of university graduates. However, despite Russia's signing the agreement on joining the Bologna process, the increasing number of graduates was due to a larger number of specialist programs which imply training for 5 years. The number of bachelors also increased, which reflects the process of the system of national education adapting to the Bologna principles, but this growth did not play a significant role in the increasing total number of graduates. The same can be said about the masters. Nevertheless, over this period the number of graduates increased by more than 12 times.

Another index which characterizes the youth labor market in Russia is the distribution of the employment of specialists who have completed a full-time training program at a state or municipal educational institution of higher education. For example, in Soviet times there was a so-called "distribution" which implied mandatory official assignment of the first job place for the graduate. The state thereby provided a guarantee of employment for each person, including a young one, thus realizing the right to work, written in the Constitution of the USSR.

Over the reform period of the $90 \mathrm{~s}$ the "distribution" was abolished and the graduates had to look for a job themselves. However, a number of universities, especially industrial ones, which have preserved the connections with the production, still have the system of distribution; though it is voluntary (i.e., graduates can choose whether to accept a job according to job placement or search for employment themselves). Anyway, the distribution is not obligatory, like it was during the Soviet era. In this respect, a specific feature of the youth labor market development is the growing number of graduates opting for a job placement (Table 2 and 3 ). 
Table 1. Graduates from the institutions of higher professional education (thousand people)

\begin{tabular}{lrrrr}
\hline & 1995 & 2000 & \multicolumn{1}{c}{2005} & 2010 \\
\hline Graduated-total number & 1729.6 & 2003.3 & 2573.5 & 2646.3 \\
All institutions of higher education: & 403.2 & 635.1 & 1151.7 & 1442.3 \\
State and municipal & 395.5 & 578.9 & 978.4 & 1166.9 \\
Private & 7.7 & 56.2 & 173.3 & 275.5 \\
Postgraduate and doctoral studies* & 11.8 & 26.1 & 34.9 & 35.5 \\
\hline
\end{tabular}

* at the end of the year

Source: Youth in Russia, 2010: Statistics Digest. UNICEF, the Federal State Statistics Service. -Moscow: IPC “Statistics of Russia”: 70.

Table 2. Graduates of educational institutions of higher education regarding their qualifications (thousands of people)

\begin{tabular}{|c|c|c|c|c|}
\hline & 1995 & 2000 & 2005 & 2010 \\
\hline Graduates, total & 403.2 & 635.1 & 1151.7 & 1442.30000 \\
\hline \multicolumn{5}{|l|}{ Of them received qualifications of: } \\
\hline Incomplete higher professional education & 1.6 & 2.3 & 4.3 & 10.10000 \\
\hline Bachelor degree & 8.0 & 71.0 & 84.6 & 124.00000 \\
\hline Specialist degree & 391.9 & 553.4 & 1051.7 & 1287.70000 \\
\hline Master degree & 1.7 & & 8.4 & 11.120 .5 \\
\hline
\end{tabular}

Table 3. Distribution of specialists, graduating from the full-time programs at the departments of state and municipal educational institutions of higher education

Educational institutions of higher education

Graduates, thousand people

The number of graduates obtaining a job placement, thousand people

The share of people who did not obtain a job placement (including those

\begin{tabular}{rrrr}
1995 & 2000 & 2005 & 2010 \\
\hline 249.6 & 315.3 & 342.0 & 395.3 \\
128.7 & 146.0 & 166.6 & 199.6 \\
42.2 & 35.7 & 35.1 & 29.4
\end{tabular}

who found a job themselves) as a percentage of the graduates

Source: Youth in Russia, 2010: Statistics Digest. UNICEF, the Federal State Statistics Service. -Moscow: IPC "Statistics of Russia": 81.

Such a situation reflects the Russian youth's desire for a stable life with a guaranteed job after graduation. The universities understand this wish of their graduates and they are trying to fulfill it, thus increasing their competitiveness.

The analysis of the situation in the youth labor market of St. Petersburg was carried out on the basis of the official data published on the site of administration of St. Petersburg in the section of statistics, which provides the information for 2014 .

According to the analytical comments given by the Committee on Information and Communications of St. Petersburg working in cooperation with the St. Petersburg Information and Analytical Centre state, despite the unfavorable processes in Russian economy, including the negative macroeconomic processes, the number of economically active population of young adults (from 20 to 29 years) has increased. It does not only mean the employment of young specialists, but also creating new jobs. In addition, it was noted that wages continued to grow, while the number of employed unofficially in 2014 rose to 84,000 people. We can assume that a young generation of workers played a significant role in this trend.

According to the Federal State Statistics Service of the Russian Federation, people of 30 to 59 are the most active group in the labor market. Their share in the structure of unemployed population is only $15.4 \%$ (the data for the labor market in St. Petersburg in 2014; Official site of the administration of St. Petersburg). The bordering groups of the economically active population, including young people of 15 to 19 years old demonstrate the lowest level of economic activity, which is the result of certain social and demographic characteristics of this group (training, birth and child care, etc.).

If we consider the structure of St. Petersburg population in 2014 , the first noticeable change is the decline in the number of young people aged 15 to 19 . This is the result of a drop in the birth rate of the 1990s due to deteriorating quality and standard of living of the population in the post-reform Russia. At the same time, among young people aged 20-29 we may see an increase in the share of economically active population, which occurred due to the crisis in the Russian economy compelling young people to start working earlier. In general, the unemployment among young people in St. Petersburg has risen.

In the post-Soviet period, finding a job was always difficult for young people. Currently, however, this problem is especially pressing. About $30 \%$ of applications to the employment offices are from the young professionals-recent graduates. On the whole, the total share of unemployed young Russians in August, 2015, amounted to 28.5\%, including 15-19 year-olds $-5.9 \%$, 20-24 year-olds $-22.6 \%$ (Federal State 
Statistics Service of the Russian Federation). In St. Petersburg in 2014 the unemployment rate among people aged $15-19$ was $1.0 \%$, but the unemployment rate among young people of 20 and 29 years old was $42.7 \%$ (gov.spb.ru). The youth unemployment is increasing parallel to the growing number of jobs for young people. One of the main reasons for this growth is the fact that Russian employers are trying save on wages of their employees, since a young specialist without work experience or with little experience can definitely be paid less than experienced workers. This stimulates the increase in the number of jobs for young people. However, young people are not in a hurry to occupy these positions because of high salary expectations (Nikiforova, 2014).

Other problems associated with the transitional state of the country's economy are also inherent in the youth labor market in modern Russia. First of all, they refer to the fact that in times of economic crisis, a large surplus of workforce was created, which has formed the employer's attitude to human resources as inexhaustible (Anoshin and Kurilchenko, 2013). Private sector employers ignore labor regulations in some cases. Often, in order to avoid taxes and social contributions hiring relationships have the form of off-the-books employment, which gives ample opportunity for employers to manifest abuse of power in relation to employees. Very often, such jobs are filled with yesterday's university graduates. The data of sociological studies confirm the thesis that the first job after graduating from university is considered by the graduates as a stepping stone to gain experience, actualize labor potential and enhance the value proposition for employers (Borisova and Timofeyev, 2014) At the same time the graduates are ready to irregular working day and to off-the-books relationships with the employer.

In addition, the problem of employing young people not in the specialty they received in high school is one of the most acute problems of youth employment in Russia. Thus, from 50 to $70 \%$ of employed graduates do not work by training (Matrosova and Gukasova, 2014). A substantial portion of students presupposes already on admission to the university that they will not work by training either because of lack of job opportunities, or because of non-compliance of their knowledge with the employer's requirements or because of higher salary expectations. This means that the workforce, which is neither in demand, nor able to compete successfully, gets to the labor market.

Fragmentary cooperation between employers and higher education as high school is one of the major reasons for this problematic situation, when the high school based on the existing and often outdated educational standards, does not see the targets for their modernization, the guidelines that could be defined by the business structures, forming the demand for graduates' labor of respective universities. Therefore, one of the ways to solve the whole complex of the youth labor market problems in Russia is the necessity for cooperation between universities and business structures regarding not only the employment of graduates, but also their training during studies in a particular university, which makes the task of analyzing the existing experience such cooperation actual.

\section{The Role of Business in Solving the Youth Labor Market Problems}

There is no doubt that business is interested in employing young professionals. In this regard, companies operating in the real sector of the economy develop their own methods of attracting young specialists. We have interviewed six experts working in six major Russian companies.

A common feature of the policies aimed at attracting young professionals into the company noted by all the experts is that these companies have shifted from making job offers to graduates to devising targeted training programs in the universities of the corresponding field. This approach allows companies to solve several problems at once. First, companies are able to influence the quality of instruction in terms of its improvement. For example, an expert from a major steel company pointed out that until 2005 (it was when the company was able to launch this project in a university with the corresponding major) the system of higher education in the company's field was in crisis. Students were taught obsolete courses of the outdated contents. When starting to work in the industry, the graduates faced the problem that the outdated knowledge they were taught is no longer applied in the company. The point is that steel industry is a high-tech one, whose technical and technological basis is updated quite rapidly. Similarly, equipment and technologies are aging rapidly; here we may primarily talk of obsolescence. That is why this area should have a closer contact between businesses and institutions of higher education, which will help to update the instruction in accordance with the introduction of new technologies in the industry. Education, as it was noted by the expert, should to a certain extent adapt to the market demands.

Almost all experts have noted that retraining of a young professional with outdated knowledge is more expensive for a company than investing in education aimed at its modernization. At the same time, students doing these programs, as an expert from a big steel company remarked, have an opportunity to combine work and study. For these students three months of study are alternated with three months of work. As a rule, this 
aspect is neglected in Russian educational system, which provides only short-term practical training for students. It should be also mentioned that over the entire period of the training program which lasts two years students are paid a salary, regardless of whether they are working or studying at this particular moment. For students, this, apart from other things, is an excellent opportunity to practice their time-management skills, as during the course of study in the program they have to change the area of their activity every three months-the students alternate between studying and working. In addition, they should find time to write a thesis, as this program enrolls best graduates of Russia doing bachelor and specialist degrees. Thus, secondly, companies are able to choose the best young staff, not by searching for them in other companies or by organizing a complicated testing procedure, but by creating an attractive environment for learning and employment, when the employees with highest potential turn up themselves.

Another important feature of this form of interaction between business and higher education is the company's participation in teacher training, when companies give teachers an opportunity to take an internship at the company. The frequency of such internships may vary, but it is assumed that they are carried out as often as required by technology and equipment upgrading at the company.

Actually, the company's focus on the quality of teaching extends further. According to the expert from a large steel company, the company also provides financial assistance to teachers, which is paid in the form of supplementary benefits. This is done not only to encourage them to higher quality work, but also to keep highly-qualified professionals on the position, so that a particular teacher does not leave to work in another company with higher salaries.

After graduation young professionals have to work at the company for 5 years and only then they can choose whether they would like to stay in this company or to seek employment on their own in another place, the company pays close attention to motivation of young employees. The large steel company we have already mentioned is currently developing new production capacities that involve the construction of a casting and rolling complex in one of the cities of the Nizhny Novgorod region. It is expected that the labor resources at the enterprise will be constituted by the youth of the Nizhny Novgorod region. In this respect, to motivate young people to work at the enterprise, the company provides this staff with apartments. At the same time the company realizes that young professionals may leave for big cities that offer rich cultural life and, thus, exchanging it for a life in a small town with one main enterprise, where the cultural life is stale and the social infrastructure is developed poorly.
Another direction of the company's activities aimed at attracting qualified young professionals to the enterprise is the development and implementation of comprehensive measures for career guidance among high school students. The children of the company's employees are the target audience during these events. For example, the company conducts a three-week camp in the Novgorod region, where high school students can get acquainted with the aspects of the company's work: They are shown a blast furnace, learn about the operation of various departments of the enterprise, programs of social support for workers, the company's cultural life. All this is done to ensure that these students will not only choose a field of study corresponding to the company's profile, but will also be motivated to work at the enterprise. Here, there is a good reason why the children of employees were chosen as the target audience. Firstly, they are the group socially closest to the company. Secondly, these students after socializing in their families have some idea of the company's activities and, therefore, are already deciding, whether they should consider this company or look for a different area of employment. Thirdly, this gives a certain confidence in the future to their parents-the company's employees.

Basic structural guidelines of this program are shown in Fig. 1.

The main benefits obtained by this company during implementation of such co-operation with higher educational establishment are:

- Recruiting a young professional with the knowledge and skills that are required in this particular company and in this particular workplace

- Saving costs of retraining young professionals so that they have mastered their operating skills to work with the technologies used in the production processes in the workplace

- Saving costs of young professionals' adaptation in the workplace, since in the process of alternating work and study such a specialist not only proves to be ready to work in the required mode, but also gets acquainted with the workforce and becomes a fullfledged member

- Saving costs of staff turnover, since those young professionals, who because of various reasons understand that they will not be able to start working in the company later, are peeled apart already during the training program

- Carrying out the selection of the best young professionals in these particular specialties from all over Russia, since the implemented program offers attractive, by Russian standards, conditions for training and employment

- Formation of a stable positive labor motivation among the company's current employees 


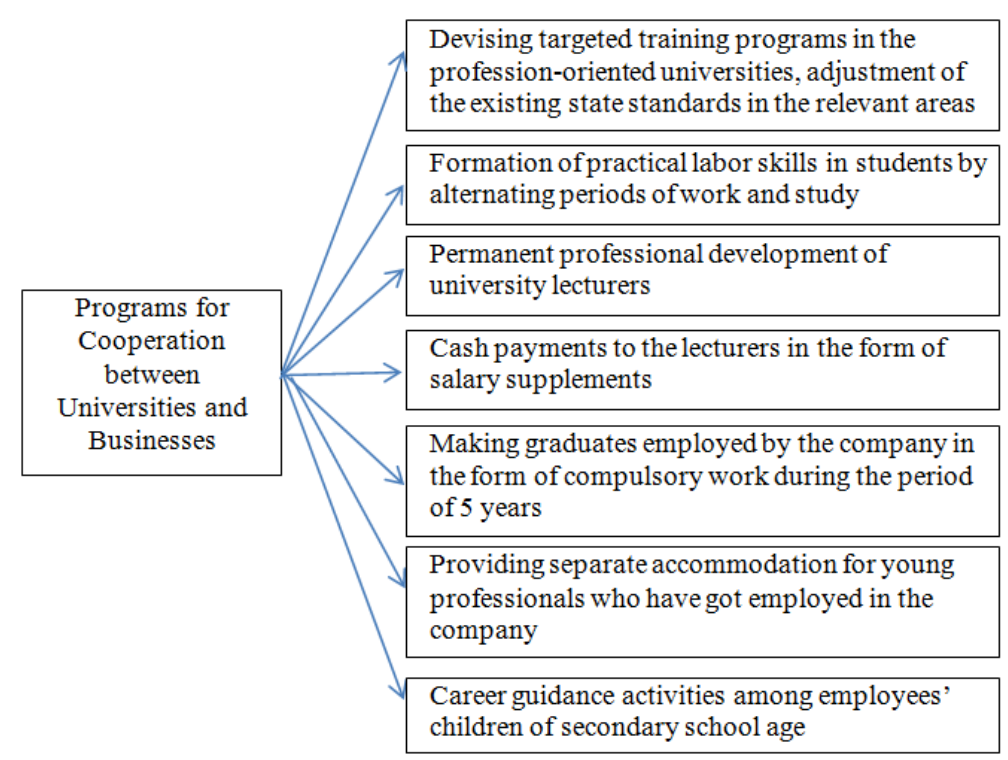

Fig. 1. Basic structural guidelines of the program for cooperation between a large steel company and a university

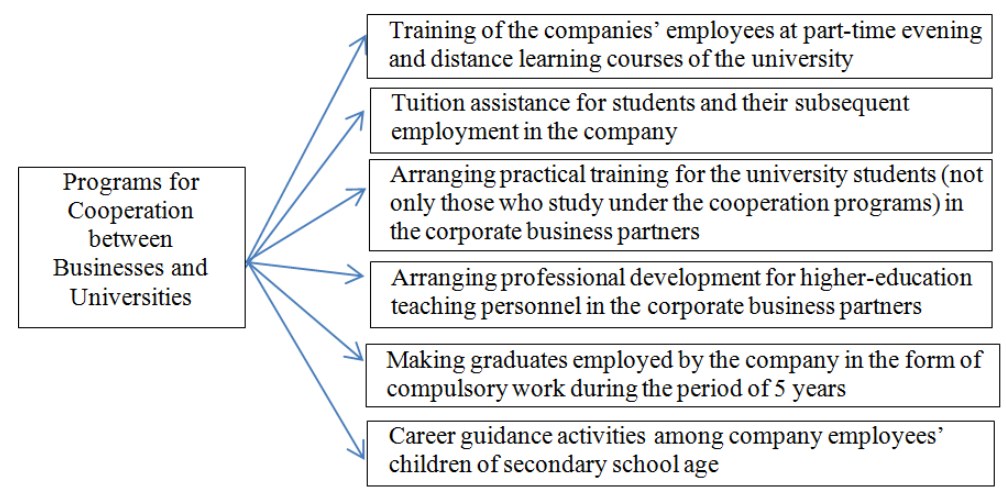

Fig. 2. Basic guidelines for implementation of interaction between shipbuilding companies and the university

The major weakness of this program is its high costs. Though in the surveyed company this program pays off by all sorts of cost savings, however this company is a large (or rather a very large) one, possessing facilities not only in Russia but in other countries, including the United States. Therefore it can afford the implementation of such programs. Small and medium companies will be unable to carry out such programs. In addition, the company should have an opportunity to employ a certain number of newly trained professionals annually without sacking already employed workers while, i.e., the company size must allow balancing the recruitment of young graduates of such program and natural staff turnover. Moreover, the company must conduct a comprehensive workforce policy aimed at creating attractive working conditions for workers to secure them for jobs in the company. Also it is worth noting that the company's facilities are located in small towns, so the company needs to be socially responsible. The weak point of implementing such a program is also the need for interaction with governmental bodies, approving educational standards for higher education.

This form of cooperation between business and higher education in the youth labor market is not a unique one. Shipbuilding companies surveyed cooperate with higher education in a slightly different form. The cooperation is carried out in two aspects. The first direction deals with paying for the employees of these companies training in the university on a corresponding program. Such students may be enrolled at a university both according to the results of a unified state exam when chosen from a particular group of students or through entrance exams conducted by a particular university itself. Moreover, despite Russia's trend of reforming education which implies elimination of parttime and distance forms of study, the universities collaborating with the interviewed companies have 
preserved these programs. This is done to give students of these companies a chance to combine work and study.

An important aspect of the companies' activities of attracting young professionals is searching among high school students those who, after graduating from university, agree to work for a certain amount of time (5 years) at the position the company needs. Like iron and steel companies, the shipbuilding companies also search for these people through network communication, namely, the main focus is on the employees with children of appropriate age. It should be mentioned that the employees actively respond to this initiative of the company, as they are interested in ensuring a stable and prosperous future for their children. The company not only pays for these students' training, but also gives a decent stipend, motivating them for better performance. Such students, unlike students already working in the company, prefer to study full-time.

Similar to the iron and steel companies, the shipbuilding companies are concerned about the quality of teaching in the specialized universities and provide various forms of professional development for teachers.

Basic guidelines for implementation of such programs are shown in Fig. 2.

The strengths of such programs of interaction between the companies and universities include:

- Less costs as compared to the steel company's cooperation program. Not only the large company, but also the average one can afford the implementation of such a program

- Ability to influence the thematic content of the courses to conform the technologies used in the production process

- No need for interaction with public authorities controlling the university

- Creation of a positive learning motivation among students, future employees of the company

- Creation of a positive labor motivation among the company's employees, since they gain confidence in securing the future of their children

- Saving costs of staff turnover, since the university graduates trained at the expense of the company must work for 5 years there

- Saving costs of young professionals' adaptation in the particular workplace

- Possibility of training for the companies' operating employees, i.e., the possibility to combine work and study

The weaknesses of this form of interaction between companies and universities are seen as follows:

- The risks of investing in the education of such students if the company will not be able to employ them at the end of the period of study, since during this period the economic situation may change
- The restricted possibilities to influence the learning process in terms of the formation of educational standards for various specialties needed by the companies

- Costs of young professionals' retraining with the aim of mastering their specialized knowledge to work precisely at the given workplace in the given company

- Costs of creating attractive working conditions for all workers and young professionals enrolled in the program, with a view to establish themselves securely in the company

The analysis of the interviews with business representatives demonstrates that the companies interested in attracting highly-qualified young professionals prefer not to search for random specialists in the labor market, but actively cooperate with the universities of the same field and work on increasing the quality of the future employees' training. In addition, future employees are selected at the stage prior to their obtaining higher education.

\section{Higher School Activities Addressing the Problems of the Youth Labor Market}

The main direction of the higher school activities aimed at facilitating the youth employment relates to its cooperation with the business, which includes various agreements on practical training of students with a perspective of employment.

The universities seek to conclude agreements with various large and medium-sized companies in order to provide students with opportunities to undergo all sorts of practices, including the introductory practical training, work experience internship and pre-graduation internship. The advantages of such cooperation for universities are as follows: Students not only get acquainted with the real production process, but also they collect material for writing various kinds of certification works stipulated by the curriculum. For the companies it is an opportunity to take a closer look at the trainees and to assess their qualification highlights from the standpoint of their possible employment in the company. In addition, most companies do not pay students for their labor force during their internship, so there is a saving on wages. The disadvantages of such cooperation between the companies and universities include the following: The trainees are entrusted only with low-skilled jobs, fulfilling which the student may not receive the full amount of knowledge about the production features of the company and also these students having no appropriate skills can make a series of errors that will result in financial losses for the company.

The need for the approval of the students' graduation qualifying papers by the representatives of the 
employing companies became one of the newest forms of cooperation between the universities and companies. Themes of such qualifying papers are offered not by the university, professors, but by the companies interested in future employment of the graduates, with regard to the specifics of their future employment duties. This form is only starting to be introduced into the practice of the learning process. Its validity is seen in the following: Firstly, the graduates' job security increases; secondly, the adaptation period is facilitated when a graduate starts working; thirdly, the companies get the possibility to select the most suitable graduates. High transaction costs of the implementation of relevant interactions between the universities and companies which did not exist previously should be referred to the disadvantages of this form of cooperation. In addition, the search for employing companies being in need of hiring young professionals within the implementation of this form falls on the shoulders of the university.

However, the formation of the youth labor market by higher school starts much earlier than actual enrollment at university-in the last year of school as a part of career guidance.

Career guidance is an important aspect of high school work now. It is organized not only by universities through running educational programs in the corresponding field, but also by business (usually big) and the state (establishing career guidance centers, creating a position of a school psychologist, etc.). This work aims to solve a problem which is extremely important for the youth labor market: When high school students, having passed their exams, enter university, doing not a course they are most interested in, but the one for which they managed to score enough points. Therefore, the learning outcomes of such students at the university are average, at best. A possible solution is helping high school students choose a specific occupation, activities most interesting to them and equip them with information on universities with the programs that interest them; the exam results will then show what particular university each school-leaver can enter.

Having analyzed the interviews, we can now identify main areas of career guidance activities of universities. First of all, it is preparation and implementation of appropriate educational programs. Lessons in these programs are conducted both at relevant universities and at schools which have joined the program. For example, the Sociology Department of one of the leading universities started the project "Interesting sociology", aimed at not only familiarizing high school students with what sociology is, as teachers cannot, as a rule, tell students about this subject (only $5 \%$ of the teachers, according to the expert's opinion, can answer the question what sociology actually deals with), but it also helps to overcome some stereotypes of everyday life (Boronoev and Skvortsov, 2005; Zyrianov et al., 2014).
Another area of career guidance involves organizing various kinds of competitions for schoolchildren. Conducting academic competitions (Academic Olympics) in various subjects is the most popular form of these. What's more, every year the Ministry of Education approves the list of competitions, the results of which will provide certain benefits when applying for a university. In addition, some universities conduct their own competitions for schoolchildren. For example, the Saint Petersburg National Research University of Information Technologies, Mechanics and Optics conducts an annual competition called "The Wind of Change". The event lasts for a week and includes various types of games and problem solving. This is both a career guidance activity and advertising of the university.

In addition to planning and conducting events directly aimed at the target audience of high school students, the universities also create assessment centers which not only work with high school students, but also with university students and graduates. For example, these assessment centers provide a comprehensive, forecasting assessment of competencies; development of professional competencies of young specialists; interaction with companies-prospective employers; contextual learning; career counseling. For example, such an assessment center was created at the Center for Employment at the St. Petersburg State University of Technology. In addition to the abovementioned functions, it regularly conducts a business game "Corporation Origami" which helps students to obtain experience of various stages of employment; it boosts their self-confidence in the professional field, promotes a responsible attitude towards professional development and career building and enables to get experience of interaction with the representatives of other occupations. The plot of the game, as a rule, is a task, according to which the players should pass all stages-from choosing a job to the first working day in Origami Corporation. The unique nature of this project is determined by the fact that, first, it was developed and is conducted by a team of experts working in various fields; second, it uses a social and competence-based approach in developing and assessing the potential of young professionals; third, it combines modern educational and HR-technologies; four, it is based on specific cases from the real practices of the companies; fifth, it requires decision-making in interdisciplinary issues, which integrates the students' knowledge of technology, economics and psychology; sixth, playing a game, students get a real result in a form of a job offer or internship at leading companies; seventh, this project can be implemented in any institution of vocational education.

Basic forms of cooperation between the Universities and business structures are shown in Fig. 3 . 


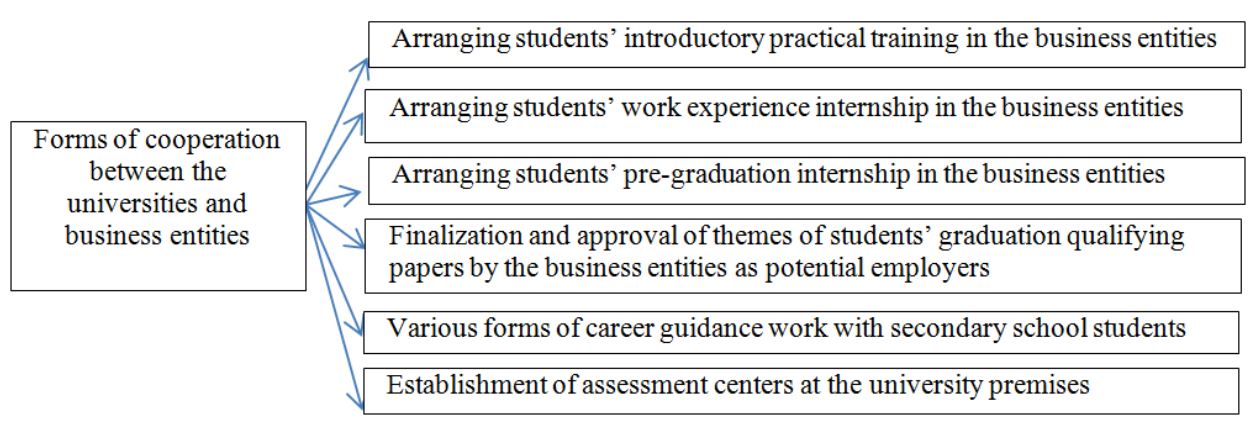

Fig. 3. Basic forms of cooperation between the Universities and business structures

In general, all interviewed experts pointed out that universities take active action regarding the solution of problems in the youth labor market. Apart from their main activity-education when universities update the educational programs and curricula of courses, they are intensely working on different issues concerning young people.

\section{Discussion}

Nowadays the theme of cooperation between business and higher education in addressing youth labor market issues becomes actively reviewed by experts of different fields of knowledge. Various studies result in the conclusion that the contacts between business structures and higher education are not sufficient (Lopatkin, 2015; Ionova et al., 2015; Anoshin and Kurilchenko, 2013; Gafurova, 2013; Grigoryeva, 2015), according to some sociological studies, only $1 \%$ of graduates are employed under a contract between the university and the employer (Anoshin and Kurilchenko, 2013). Our study revealed that the contacts between the companies surveyed by us and the relevant higher educational institutions were sufficiently dense. At the same time the major shipbuilding companies collaborated with the specialized university as far back as in the Soviet times, in the post-reform period the form of cooperation had to be adapted to the new conditions. With regard to the metallurgical company, its close cooperation with the specialized institution refers to the post-Soviet times already, but this company is very large and can therefore afford appropriate substantive content of its relationship with this university. Thus, it is possible to state that only large businesses are mainly cooperating with the universities now, they are trying to choose for themselves the best young staff, the percentage of which in the production of young professionals is very small.

According to the data obtained as a result of various studies, several levels of cooperation between business and higher education are distinguished: (1) The organization of various kinds of students' practices on the basis of appropriate business structures; (2) provision of information for the universities regarding job vacancies in business structures; (3) making contracts between the business structures and universities for training specialists (Morrenweiser, 2012; Ionova et al., 2015; Matrosova and Gukasova, 2014; Borisova and Timofeyeva, 2014; Anoshin and Kurilchenko, 2013). In the course of our research it became clear that the cooperation between the business structure and university can be deeper than the mentioned levels and refer to the impact of the business structures on the educational process itself, including the organization of individual training areas with the approval of educational standards in the relevant state bodies.

Also, the studies note the need not only to diagnose suitability of applicants and students, but also to monitor the dynamics of readiness to succeed in the profession (Borisova and Timofeyeva, 2014), which overlooked by the universities and business organizations, concluding contracts for specialist training with them. It was found out in our study that the main social source of students, who are studying under a contract between the business structures and the universities, is a contingent of children whose parents are employed by these business structures. Family relations are dominant not only in the choice of profession, but also in building the carrier, which negates the value and diagnostics of professional suitability and appropriate monitoring. This explains why neither the universities nor the companies have any desire to carry out them. This also updates the need for studying such a widespread phenomenon in the Russian labor relations as nepotism, the presence of which is denoted by researchers as one of the most acute problems (Lopatkin, 2015).

The results of our research confirm the basic theoretical provisions of the political-cultural approach in the economic sociology (Fligstein, 2001). The surveyed companies and universities are seeking to stabilize their position in the market environment by establishing social contact with each other, aimed at creating a long-term collaboration in the form of implementation of the relevant social strategies. These strategies vary according to the economic capacity of businesses, social and historical conditions of their (businesses') operation. 


\section{Conclusion}

The analysis of the study results lets us conclude the following:

At present time in Russia the problem of the youth employment can be solved through intensifying partnerships between higher education and business. Although the state has a significant impact on the youth labor market, the cooperation of higher school and business is becoming a leading factor in this field. At the same time our study showed that large and very large companies cooperate with the higher educational institutions on a regular basis, as a rule.

As a result of the study it was revealed that in addition to three levels identified in the scientific literature, the cooperation of businesses and universities formed another deeper level-the level of initiation to establish special areas of young professionals' training in the relevant institution needed by this particular business structure with its state accreditation when the business structure directly determines what kind of knowledge these professionals will receive, which costs less than their subsequent re-training in the workplace.

The study showed that the programs for cooperation between business structures and high schools have no diagnostics of professional suitability and monitoring of readiness to succeed in the profession in relation to the students enrolled under the contract between the business structure and the university. The main emphasis is made on the children of the employees of these business structures, when the family ties become the dominant factor in admissions under the corresponding program. This reproduces such very acute problem typical of Russian labor relations as nepotism.

\section{Acknowledgement}

The authors would like to gratefully acknowledge the unknown reviewers for their review and helpful comments.

\section{Author's Contributions}

Yury Vladimirovich Mishalchenko: Interviewed 3 experts, coordinated the mouse work, coordinated the data-analysis, contributed to the writing of the text.

Elena Eugenievna Tarando: Designed the research plan and organized the study, coordinated the dataanalysis, contributed to the writing of the text.

Alexander Fedoseevich Borisov: Interviewed 3 experts, coordinated the data-analysis, contributed to the writing of the text.

Nikolay Alexandrovich Pruel: Designed the research plan and organized the study, coordinated the data-analysis, contributed to the writing of the text.

Tatiana Borisovna Malinina: Interviewed 3 experts, coordinated the data-analysis, contributed to the writing of the text.

\section{Ethics}

The authors have no conflicts of interest in the development of the research and publication of this article.

\section{References}

Aceleanu, M.I., A.C. Serban and C. Burghelea, 2015. Greening" the youth employment-a chance for sustainable development. Sustainability, 7: 2623-2643. DOI: $10.3390 /$ su7032623

Adamoniene, R. and A. Astromskienne, 2013. Connection of youth entrepreneurial activity and value principles. Public Policy Admin., 12: 471-482. DOI: 10.5755/j01.ppaa.12.3.5295

Alegre, M.A., D. Casado, J. Sanz and F.A. Todeschini, 2015. The impact of training-intensive labour market policies on labour and educational prospects of NEETs: Evidence from Catalonia (Spain). Educ. Res., 57: 151-167. DOI: $10.1080 / 00131881.2015 .1030852$

Alzua, M.L., L. Gasparini and F. Haimovich, 2015. Education reform and labor market outcomes: The case of argentina's ley federal de educación. J. Applied Econom., 18: 21-43.

DOI: $10.1016 / \mathrm{S} 1514-0326(15) 30002-7$

Anoshin, A.V. and E.I. Kurilchenko, 2013. Directions for integration of labor market and market of educational services in the sphere of higher education of the Udmurt Republic. Standard Liv. Populat. Russian Regions, 6: 63-69.

Bezrukova, O.N., 2013. Ottsovstvo v transformirujushchemsya obshchestve: Ozhidaniya materey i praktiki ottsov. Sotsiologicheskie Issledovaniya, 11: 118-130.

Bezrukova, O.N., 2014. Modeli roditelstva i roditelskiy potentsial: Mezhpokolennyy analiz. Sotsiologicheskie Issledovaniya, 9: 85-97.

Borisova, A.A. and A.Y. Timofeeva, 2014. University graduates in the labor market: Monitoring indicators and the profile employment restraints. Univ. Manage. Pract. Anal., 1: 71-80.

Boronoev, A.O. and N.G. Skvortsov, 2005. Sotsiologiya i sociologicheskoe obrazovanie v SanktPeterburgskom universitete: Traditsii i sovremennost. Sotsiologicheskie Issledovaniya, 8: 130-139.

Chekanova, T.E., 2015. The problem of youth unemployment in Russia as a priority problem of the modern labor market. WORLD: Modernizat. Innovat. Dev., 6: 171-177.

Crepon, B., E. Duffo, M. Gurand, R. Rathelot and P. Zamora, 2013. Do labor market policies have displacement effects? Evidence from a clustered randomized experiment. Q. J. Econom., 128: 531-580. DOI: $10.3386 /$ w18597 
Demidova, O., E. Marelli and M. Signorelli, 2015. Youth labour market performances in the Russian and Italian Regions. Econom. Syst., 39: 43-58. DOI: 10.1016/j.ecosys.2014.06.003

Dudina, V.I., 2013. Vymyshlennyy krizis sotsiologii i kontury novoy epistemologii. Sotsiologicheskie Issledovaniya, 10: 13-21.

Dudina, V.I., 2015. Sotiologicheskoe znanie v kontekste razvitiya informatsionnyh tehnologijy. Sotsiologicheskie Issledovaniya, 6: 13-22.

Fligstein, N., 2001. The Architecture of Markets: An Economic Sociology of Twenty-First-Century Capitalist Societies. 1st Edn., Princeton University Press, Princeton, ISBN-10: 0691005222, pp: 274.

Fong, E. and J. Tsutsui, 2015. The high cost of missing a boat under the Japanese recruitment practices: Timing of regular and non-regular employment after school completion in Japan. Res. Soc. Stratificat. Mobility, 42: 1-10. DOI: 10.1016/j.rssm.2015.06.002

Gafurova, A.A., 2013. The education system as a fundamental factor of human capital development and increase in the level of the economic potential of the region (as exemplified by Ulyanovsk Region). Nat. Interests: Priorities Security, 13: 29-38.

Grigoryeva, I.V., 2015. On some problems and how to integrate agricultural high school and agribusiness. Bull. Upper Volga Agribus., 2: 90-94.

Hardgrove, A., E. Rootham and L. McDowell, 2015. Possible selves in a precarious labour market: Youth, imagined futures and transitions to work in the UK. Geoforum, 60: 163-171. DOI: $10.1016 /$ j.geoforum.2015.01.014

Hardi, J.H., 2015. Women's work? Predictors of young men's aspirations for entering traditionally femaledominated occupations. Sex Roles, 72: 349-362. DOI: $10.1007 / \mathrm{s} 11199-015-0449-1$

Herault, N. and R. Zakirova, 2015. Returns to education: Accounting for enrolment and completion effects. Educ. Econom., 23: 84-100. DOI: $10.1080 / 09645292.2013 .805184$

Ionova, M.L., N.V. Fadeenko and L.N. Kuroedov, 2015. Complex problems of education, implementation of the labor potential reproduction process at the enterprises and youth labor market at the present stage. Interexpo Geo-Siberia, 3: 68-72.

Ivanov, D.V., 2012. K teorii potokovykh struktur. Sotsiologicheskie Issledovaniya, 4: 8-16.

Ivanov, D.V., 2013. Etapy evolyutsii sotsiologii i dominantnye tipy teoretizirovanija. Sotsiologicheskie Issledovaniya, 9: 3-13.

Junakar, P.N., 2015. The impact of the Global Financial Crisis on youth unemployment. Econom. Labor Relat. Rev., 26: 191-217. DOI: $10.1177 / 1035304615580536$
Kamimura, Y. and N. Soma, 2013. Active labour market policies in Japan: A shift away from the companycentred model? J. Asian Public Policy, 6: 42-59. DOI: $10.1080 / 17516234.2013 .767420$

Kapustkina, E., M. Sinyutin and Y. Veselov, 2008. A note on entrepreneurial trust in the Saint-Petersburg Region of contemporary Russia. Int. J. Entrepreneurship Small Bus., 6: 94-102. DOI: $10.1504 /$ IJESB.2008.017392

Kapustkina, E.V., 2008. The system of business financing in Russia: The gender aspect. Int. J. Entrepreneurship Small Bus., 5: 297-317. DOI: 10.1504/IJESB.2008.017305

Lalthapersad-Pillay, P., 2014. Gender influences in the labour market: The case of BRICS. Mediterranean J. Soc. Sci., 5: 146-155.

Lopatkin, I.V., 2015. The youth segment of the labor market in Saratov Region: Adaptation to modern realities and stability. Politology, 15: 56-58.

Matrosova, E.G. and N.R. Gukasova, 2014. Innovative design as the imperative of implementing competence-based approach in higher education. Economy Entrepreneurship, 12: 395-399.

Morrenweiser, J., 2012. Which firms train disadvantaged youth. Empirical Res. Vocat. Educ. Train., 4: 115130.

Nikiforova, O.A., 2014. Professionalnoe Samoopredelenie Vypusknikov Vuzov na Rynke Truda Sankt-Peterburga. In: Modern Society and Work: A Collection of Works, Karapetyan, R.V., A.A. Rusalinova and O.A. Taranov (Eds.), Depatment of Economy of the St. Petersburg State University, Saint-Petersburg, pp: 802-810.

Potravnaya, E.V., 2015. The socio-historical analysis of the economic behavior of students and graduates in the labor market. Econom. Revival Russia, 3: 166-173.

Premand, P., S. Brodman, R. Almeida, R. Grun and M. Barouni, 2016. Entrepreneurship education and entry into self-employment among university graduates. World Dev., 77: 311-327.

Rasskazov, S., M. Rubtcova, P. Derugin, N. Prujel and V. Malyshev, 2016. Social network analysis as an organizational diagnostic tool: The case of small business in Russia. Int. Rev. Manage. Market., 6: 170-176.

Rubtcova, M., O. Pavenkov, V. Pavenkov and V. Elena, 2015a. The language of altruism: Corpus-based conceptualization of social category for management sociology. Asian Soc. Sci., 11: 289-297.

Rubtcova, M., O. Pavenkov, V. Pavenkov and N. Martianova, 2015b. Deprofessionalisation as a performance management dysfunction: The case of inclusive education teachers in Russia. Asian Soc. Sci., 11: 339-349. 
Rubtcova, M., O. Pavenkov, V. Pavenkov and E. Vasilieva, 2015c. Representations of Trust to public service in russian newspapers during election time: Corpusbased content analysis in public administration sociology. Mediterranean J. Soc. Sci., 6: 436-444. DOI: $10.5901 / \mathrm{mjss} .2015 . v 6 n 4 s 1 p 436$

Rubtsova, M., E. Kapustkina, R. Karapetyan, I. Kovalev and S. Rasskazov, 2015. The social environment and business communication in English: A small-scale research on front-line staff performance in Russia, Spain and France. Int. Rev. Manage. Market., 5: 253-258.

Rubtsova, M.V., 2007. Upravlyaemost: Teoretikosotsiologicheskiy analiz ponyatiy. Sotsiologicheskie Issledovaniya, 12: 32-38.

Rubtsova, M.V., 2011. Upravlyaemost vo vzaimodeystvii subjektov: Traditsionnye i novye praktiki. Sotsiologicheskie Issledovaniya, 2: 46-53.

Sasaky, M., V.A. Davydenko, G.F. Romashina and V.V. Voronov, 2013. Sravnitelnyy analiz doverijya V razlichnykh stranakh. Sotsiologicheskie Issledovaniya, 3: 60-73.

Signorelli, M. and M.T. Choudhry, 2015. Symposium: Youth labour market and the "Great Recession". Econom. Syst., 39: 1-2.

DOI: $10.1016 /$ j.ecosys.2014.06.005
Vasiliev, A.A., 2014. Youth labor market in 1992-2014. Power, 12: 31-35.

Vasilieva, E., M. Rubtcova, V. Kaisarova, A. Kaisarov and O. Pavenkov, 2015. Personal targets for public servants and their support the governance's performance conception in Russia. Int. Rev. Manage. Market., 5: 246-252.

Veselov, Y.V., 2015. Povsednevnye praktiki pitaniya. Sotsiologicheskie Issledovaniya, 1: 95-104.

Voronov, V.V., O.Y. Lavrinenko and Y.V. Stashane, 2014. Otsenka dinamiki mezhregionalnykh razlichiy (Evropeyskiy opyt). Sotsiologicheskie Issledovaniya, 1: 29-39.

Youth in Russia, 2010: Statistics digest. UNICEF, the Federal State Statistics Service. IPC "Statistics of Russia", Moscow.

Zyrianov, V.V., L.V. Temnova and E.A. Saiko, 2014. Monitoring osnovnyh obrazovatelnykh programm po napravleniyu «Sotiologiya»: Problemy i tendencii. Sotsiologicheskie Issledovaniya, 5: 139-143. 